\title{
Wildlife Management in Nunavik: Structures, Operations, and Perceptions Following the James Bay and Northern Quebec Agreement
}

\author{
Nicole Gombay ${ }^{1}$
}

(Received 5 September 2017; accepted in revised form 22 January 2019)

\begin{abstract}
Among the functions of the James Bay and Northern Quebec Agreement (JBNQA) was the establishment of a series of mechanisms to enable its Indigenous signatories to continue their subsistence practices. Central to these mechanisms were commitments to create a co-management regime for the area's wildlife. In 1995, 20 years after the Agreement was signed, Lorraine Brooke published an analysis of Inuit experiences of the regime. This article extends her study, presenting the present structures of wildlife management in Nunavik, particularly as of the mid-2000s. It explores the extent to which the federal and provincial government commitments laid out in the JBNQA have been fulfilled and assesses the contemporary relevance of Brooke's conclusions. Based on interviews with Inuit and non-Inuit stakeholders, including bureaucrats and individual hunters and fishers, the paper outlines the diverse perspectives of those who administer and who are subject to the enforcement of Nunavik's wildlife management regime. It concludes that many of the findings from Brooke's analysis persist. The region continues to be subject to complex bureaucratic and administrative structures that routinely make power sharing between Inuit and non-Inuit government agencies problematic.
\end{abstract}

Key words: Inuit; Indigenous; James Bay and Northern Quebec Agreement; Nunavik; wildlife management; land claims; subsistence; co-management

RÉSUMÉ. Parmi les modalités de la Convention de la Baie-James et du Nord québécois (CBJNQ), notons l'établissement d'une série de mécanismes permettant à ses signataires autochtones de continuer à exploiter les ressources à des fins de subsistance. Une série d'engagements visant à créer un régime de cogestion de la faune de la région était à la base même de ces mécanismes. En 1995, 20 ans après la signature de la convention, Lorraine Brooke a publié une analyse au sujet des expériences des Inuits par rapport à ce régime. Cet article se veut le prolongement de son étude et présente les structures actuelles de gestion de la faune du Nunavik, plus particulièrement depuis le milieu des années 2000. L'article explore la mesure dans laquelle les engagements du gouvernement fédéral et du gouvernement provincial énoncés dans la CBJNQ ont été respectés, et évalue la pertinence contemporaine des conclusions de Lorraine Brooke. En se fondant sur des entrevues réalisées auprès d'intervenants inuits et non inuits, y compris des bureaucrates ainsi que des chasseurs et des pêcheurs particuliers, l'article fait état des diverses perspectives de ceux qui administrent le régime et de ceux qui sont assujettis à l'application du régime de gestion de la faune du Nunavik. Il conclut que grand nombre des constatations découlant de l'analyse de Lorraine Brooke sont encore valables. La région continue de faire l'objet de structures bureaucratiques et administratives complexes qui rendent problématique le partage du pouvoir usuel entre les organismes gouvernementaux inuits et non inuits.

Mots clés : Inuit; Autochtone; Convention de la Baie-James et du Nord québécois; Nunavik; gestion de la faune; revendications territoriales; subsistance; cogestion

Traduit pour la revue Arctic par Nicole Giguère.

\section{INTRODUCTION}

Across Inuit Nunangat, demand for primary resources, coupled with climate change, is compelling the Inuit to confront increased pressure on the resources of their territories. Furthermore, in Nunavik - the Inuit region of northern Quebec created as a result of the James Bay and Northern Quebec Agreement (JBNQA) - the provincial government's Plan Nord will escalate and facilitate resource development in the region (see Gouvernement du Québec, 2015; Fabbi et al., 2017). Launched by the
Government of Quebec in 2011, Plan Nord is a 25-year economic development initiative involving the region north of the 49th parallel. Its focus is on energy, mining, forestry, tourism, and bio-foods.

The challenge confronting the Inuit and the various governments operating on their homelands is to determine just how increased resource development will affect the sustainability of the territory (Canadian Polar Commission, 2014; Rodon and Schott, 2014). The leadership of various Inuit organizations is now also facing the prospect of promoting resource development; with growing

\footnotetext{
${ }^{1}$ Department of Geography, Université de Montreal, 520 ch. de la Côte-Sainte-Catherine, PO Box 6128, Centre-Ville STN, Montreal, Québec H3C 3J7, Canada; nicole.gombay@umontreal.ca

(C) The Arctic Institute of North America
} 
populations, this may appear to be the only route to finance their endeavours and provide employment for the people they represent (KRG and Makivik Corporation, 2010). Inuit therefore recognize the challenges of balancing subsistence activities with other forms of development that have and will occur on their lands.

Pressures on the conditions necessary to sustain Inuit hunting, fishing, and trapping are not new. They are manifestations of the ongoing impacts of centuries of settler colonial invasion and occupation through which the loss of territorial control and self-determination became central features of Indigenous peoples' struggles to preserve their lands and ways of life. They are also essential components of proclamations and treaties that Indigenous peoples have signed first with imperial and later settler colonial governments. Amongst others, these treaties represented covenants by these governments to provide services and reserve lands for Indigenous peoples in exchange for the right of shared occupation. An important element of those promises is the right to preserve the conditions that allow Indigenous peoples to continue their subsistence practices. Yet in the aftermath of these claims, some question their efficacy. They argue that the land claims, far from enabling the creation of effective systems of Indigenous governance, embody and perpetuate settler colonial modes of conceiving of land and resources, entrenching non-Indigenous values and practices-including management systems-that promote resource extraction and threaten the very activities Indigenous peoples were seeking to protect (Gagnon, 1982; Brooke, 1995; Alfred, 2005; Suluk and Blakney, 2008; Coulthard, 2014; Rodon, 2014; Kulchyski, 2015). As we shall see, for the Inuit of Nunavik the outcomes of the JBNQA do, in some ways, appear to confirm such concerns (see Brooke, 1995; Fenge, 2008, 2013; McCarthy, 2013; Orkin, 2013).

In a Canadian context the James Bay and Northern Quebec Agreement is historically significant. Signed in 1975, it was the first modern, comprehensive land claim in Canada. As such, it represents a landmark whose outcomes, with the passage of time, merit closer scrutiny. To what degree have the commitments undertaken by the federal and provincial governments been fulfilled? Given the struggle of Indigenous parties to the JBNQA during the negotiations to preserve the conditions that would permit them to continue to practice their subsistence activities, what has been the outcome?

In this context, this article will examine the ways in which wildlife management in Nunavik has developed in the aftermath of the JBNQA. It will pay particular attention to the institutions and mechanisms that determine the management of the territory's wildlife and discuss the degree to which, and some of the reasons why, the various structures agreed to in the land claims have been realized.

In doing so, it will update Brooke's analysis of 1995. Her work documents Inuit experiences during the first 20 years of Nunavik's wildlife management regime. As such, it serves as a benchmark for future such analyses.
Among other difficulties, she notes that the Inuit had to contend with complex bureaucratic and administrative structures; poor power-sharing arrangements between Inuit and non-Inuit; lack of common belief systems structuring wildlife management, with a consequent undermining of Inuit concepts and systems of resource use and management; lack of control by Inuit over lands and resources; poor communication leading to disengagement on the part of Inuit and an inability to make joint decisions effectively; combative relations between Inuit and state regulators; insufficient funding for the implementation of management structures; and struggles with governments over the interpretation and application of the JBNQA, thus necessitating the negotiation of further agreements. Approximately 20 years after Brooke's article and 40 years since the JBNQA was signed, it is worth considering the degree to which these issues persist.

My findings are based partially on 29 recorded interviews personally conducted in Kuujjuaq and Puvirnituq, Nunavik, and in southern Quebec between 2006 and 2008. These were verified and updated in 2018 (details below). Both Nunavik settlements are large, regional centres with significant non-Inuit populations. They have played important opposing roles in the implementation of the JBNQA. Kuujjuaq, as an administrative centre, has become the hub of regional and provincial management facilities and operations. Whereas Puvirnituq, which refused to sign the JBNQA, questioned the Agreement's fundamental legitimacy. The interviews, which involved 11 Inuit and 18 non-Inuit, included employees of local, regional, provincial, and federal wildlife management bureaus, representatives of Inuit organizations - including Makivik Corporation, Kuujjuaq's landholding corporation, and members of the regional and community hunting, fishing, and trapping associations (see below for more discussion) - owners of outfitting camps, members of co-management boards, and Inuit and non-Inuit inhabitants of the two settlements. Participants were selected either because they were representatives of agencies involved in wildlife management or, using the snowball sampling technique, because they were actively engaged in hunting, fishing, or trapping. Amongst the nonInuit were people who had lived in the region for anywhere from two to over 30 years. Although the initial interviews took place in 2006-08, it is significant that many of the issues the respondents brought up were echoed in a fiveyear protection plan $(2010-15)$ that was elaborated for Nunavik's wildlife resources (KRG et al., 2010). In 2018, the details of these earlier interviews were verified and updated through 11 unrecorded interviews (9 Inuit; 2 nonInuit) in Puvirnituq and Kuujjuaq with representatives of both public and ethnic agencies involved in wildlife management. Where significant changes occurred in the interim, I make note of these. Interview responses cited in the paper are presented anonymously.

To understand the elaboration of state-based wildlife management after the signing of the JBNQA we need to 
grasp the structural mechanisms on which it is founded. The circumstances under which the JBNQA was signed are therefore outlined below, as are the fundamental building blocks it established for wildlife management in Nunavik. I introduce the various laws, regulations, and government and non-government actors, as well as subsequent agreements signed between Inuit and provincial, federal, territorial, and Indigenous governments and agencies that have shaped the formal mechanisms for wildlife management in the region. I examine the ways in which the enforcement of regulations has evolved since signing of the Agreement and review some of the reasons for changes that were brought about in the mid-2000s. I conclude with an assessment of the perceptions of various stakeholders in Nunavik's wildlife management regime, in light of Brooke's analysis of the same structures.

\section{LAND CLAIMS AND NEW REGIMES OF GOVERNANCE}

Nunavik was created in response to massive resource development that threatened the subsistence practices of the Indigenous peoples of the region. In 1971 the government of Quebec announced plans to develop hydroelectricity on rivers flowing primarily into James Bay. It had not informed, let alone consulted or gained permission from, the Cree, Inuit, and Naskapi, on whose territories the development was to take place. Following a court battle, where they managed to bring the development to a brief halt, the Inuit and Cree (and later the Naskapi) were ultimately obliged to negotiate a land claims agreement. With construction already begun, the JBNQA was brokered at breakneck speed (see Rouland, 1978 and La Rusic et al., 1979 for a time line). In exchange for extinguishment of their title to the land, the Indigenous parties to the Agreement were promised a number of rights and services by the federal and provincial governments, including those in the realm of wildlife management. In this regard, Feit (1979) identifies four issues of concern to the Cree at the time of these negotiations. First, that their right to hunt at all times and in all places with a minimum of oversight be entrenched. Second, that they have an effective role in wildlife management. Third, that conflicts with nonIndigenous hunters and fishers be resolved. Fourth, that any future development not have an impact on the subsistence activities of the region's Indigenous peoples. These issues explain the centrality of the wildlife management regime in the Agreement.

Similarly, in policy statements issued since the JBNQA's conclusion, Inuit have repeatedly stressed their desire to preserve the conditions necessary for the continuation of their subsistence activities. These statements include Plan Nunavik (KRG and Makivik Corporation, 2010), Parnasimautik (Makivik Corporation et al., 2014), and the "2015 Nunavik Inuit Declaration: Proud, United and Determined" (Makivik Corporation, 2015). In
Parnasimautik (Makivik Corporation et al., 2014:39), Inuit are unequivocal that governments have failed to live up to their commitments concerning wildlife management. They stress the need for "partnership" with the government, the protection of their harvesting areas, and the requirement to devolve wildlife management, monitoring, research, conservation, and enforcement to the regional level. In the Nunavik Inuit Declaration (Makivik Corporation, 2015:1, 2 ), they insist that relations with government and industry be based on "equality and mutual respect," and stress that Inuit place a "priority of subsistence wildlife harvesting over all other uses." The emphasis on "partnership" and "equality and mutual respect" underscore the conditions Inuit see as necessary for relations with non-Inuit. Yet as researchers have pointed out, Inuit have been frustrated by the failures and delays in implementing the JBNQA's environmental and wildlife management regimes (Gagnon, 1982; Brooke, 1995; Peters, 1999).

Despite the declared gap in fulfillment of legal co-management responsibilities, researchers comparing the region to northern jurisdictions elsewhere in Canada consider that Inuit in Nunavik have gained a superior degree of independence from federal and provincial governments (Rodon and Grey, 2009; Coates et al., 2014; Wilson, 2017). All the same, these researchers acknowledge the challenges presented with self-government, particularly in light of the fact that the management structures it gave rise to are essentially reflections and impositions of non-Inuit modes of governance. Brooke's assessment (1995:i) was that such impositions in the realm of wildlife management had rendered the regime set up by the JBNQA "inadequate" and had "left a legacy of frustration and incompetence for all participants." It is important, therefore, not only to consider some of the formal elements that structure wildlife management in Nunavik, but also to assess the degree to which these have been effectively implemented.

The components of the Agreement that principally define Nunavik's wildlife management regime are Sections 3,7 , and 24 . To understand how they function, we need to consider the ways in which people (section 3) and property (section 7) have combined to determine just how access to the wildlife in the region is regulated (section 24). As we shall see, each component constructs and sustains the others, and collectively they define how wildlife management functions in Nunavik.

In general, wildlife management can only be understood as fundamentally linked to the property relations that regulate access and withdrawal, management, exclusion, and alienation of the resources involved, whether material or immaterial (Schlager and Ostrom, 1992). This linkage raises questions about the bases on which these property rights are determined. At the same time, constructions of property itself need fundamentally to be understood as resting upon the beliefs and social institutions that define and regulate property (Banner, 1999). Ultimately, in other words, property is best understood not so much in terms of people's rights to things, but in terms of the relations 
between people with respect to things (Singer, 2000). To understand how systems of property function, we need to clarify the social relations that construct them. Property and social relations can then be situated as essential components of a wildlife management apparatus.

The JBNQA developed two key mechanisms to delineate access, withdrawal, management, exclusion, and alienation of resources. These entailed creating new, legally defined categories for people and land. The categories can be seen as tools to protect and promote Inuit subsistence practices, but they also served as a means to legitimize legally the opening up of lands and resources to the settler state and its populace.

\section{PRODUCING NEW PEOPLE}

The Agreement (section 3) divides the population of Nunavik into "beneficiaries" (who have come to be synonymous with Inuit) and non-beneficiaries (nonInuit) (Grammond, 2008). For the purposes of wildlife management, the latter are further differentiated into "resident" and non-resident. Each has a different meaning according to the agency regulating their activities. For the province of Quebec, non-residents are non-beneficiaries who do not live in Quebec. For landholding corporations (see below), the status of non-beneficiary resident and nonresident is determined independently by each municipality according to the number of consecutive years an individual has lived in the settlement. In Kuujjuaq in 2018, for example, non-beneficiaries become residents after 12 consecutive years of residence in the town. Depending on their residency status, non-beneficiaries also have particular hunting and fishing rights, and particular fees levied against them for these rights.

With the aim of protecting Indigenous subsistence production and reducing conflict over resources, beneficiaries and non-beneficiaries have hierarchically differentiated rights to wildlife (see Feit, 1979; Gagnon, 1982; Otis, 2002). Subject to the principle of conservation (paragraph 24.1.5 and subsection 24.2), and according to guaranteed levels, harvesting by beneficiaries has priority (subsection 24.6). This priority applies to hunting, fishing, and trapping, with trapping-subject to some limitations (paragraph 24.3.20) - being exclusive to Inuit. Once these needs have been met, and subject to restrictions, the Agreement permits sport hunting and fishing by non-Inuit (subsection 24.8), with Quebec residents having greater rights than non-residents. Finally, at the bottom of the hierarchy is commercial food production for export from the region. Again, this is subject to government quotas and may only be permitted if all other needs have been met. For Inuit, then, the key function is harvesting whereas for nonInuit, the key function is sport.

Having thus defined people (and their rights of access to and withdrawal of resources), the JBNQA consequently defined their property relations. As we shall see, during the negotiations this involved serious discord.

\section{PRODUCING NEW PROPERTY RELATIONS}

From the outset, negotiations over the land regime were problematic for the Inuit. Since it was already theirs, the notion of "claiming" land made no sense to some. In addition, the requirement to extinguish their title was deeply troubling. As a result, three communitiesPuvirnituq, Salluit, and Ivujivik - initially refused to sign the Agreement (see ITN, 1977; Rouland, 1978; Brooke, 1995; Canobbio, 2009; Qumaq, 2010; Hervé, 2017b; Nungak, 2017). Today, Puvirnituq is the only holdout. In addition, the government subjected the Inuit to apparently arbitrary restrictions, limiting their selection of land to $50 \%$ of the coastline, despite the fact that Inuit are fundamentally a maritime people. Moreover, what lands they did select were whittled away to meet other demands of government and third parties, such as mining companies (Brooke, 1995). Eventually, however, most Inuit identified and claimed their lands according to the regime laid out in the Agreement.

Section 7 of the JBNQA divided Nunavik land into three categories: I, II and III (Fig. 1). The administrative and use rights associated with each category depends on one's status as beneficiary or non-beneficiary. A fundamental and problematic feature of this system is that it created settlement-specific territories. Historically, however, Inuit moved seasonally to locations within a wide area. Their gradual move to settlements in the 1950s confined them to areas that did not reflect the far larger territories they had used and with which they were affiliated. The rigidly delineated, settlement-specific land categories created by the JBNQA thus countermand the flexibility of use that is inherent to Inuit hunting, fishing, and trapping practices. They leave Inuit access to wildlife subject to non-Inuit frameworks of classification, restriction, and administration (Brooke, 1995). Hence, for example, although Inuit in northern Quebec had traditionally frequented offshore islands to hunt, fish, and gather, the letter of the law laid out in the Agreement prevented them from doing so, as these islands were outside their jurisdiction.

Title to JBNQA Category I lands belongs to Inuit landholding corporations (LHCs) created in all of the settlements that signed on to the Agreement. The lands themselves may not be sold or ceded except to the Crown, and their subsurface rights remain with the Province of Quebec. They are subject to expropriation by both federal and provincial governments, but in the event that this occurs, the relevant government must either replace them with similar lands or provide monetary compensation, according to the LHC's preference (see Gagnon, 1982; Otis, 2002). The ethnically based landholding corporations are controlled by beneficiaries and are empowered to manage and develop Category I lands. Beneficiaries have exclusive hunting and fishing rights in these lands, although nonbeneficiaries may do so if permitted by the relevant LHC.

Category II lands are owned by the province of Quebec, but beneficiaries have exclusive hunting, fishing, and 


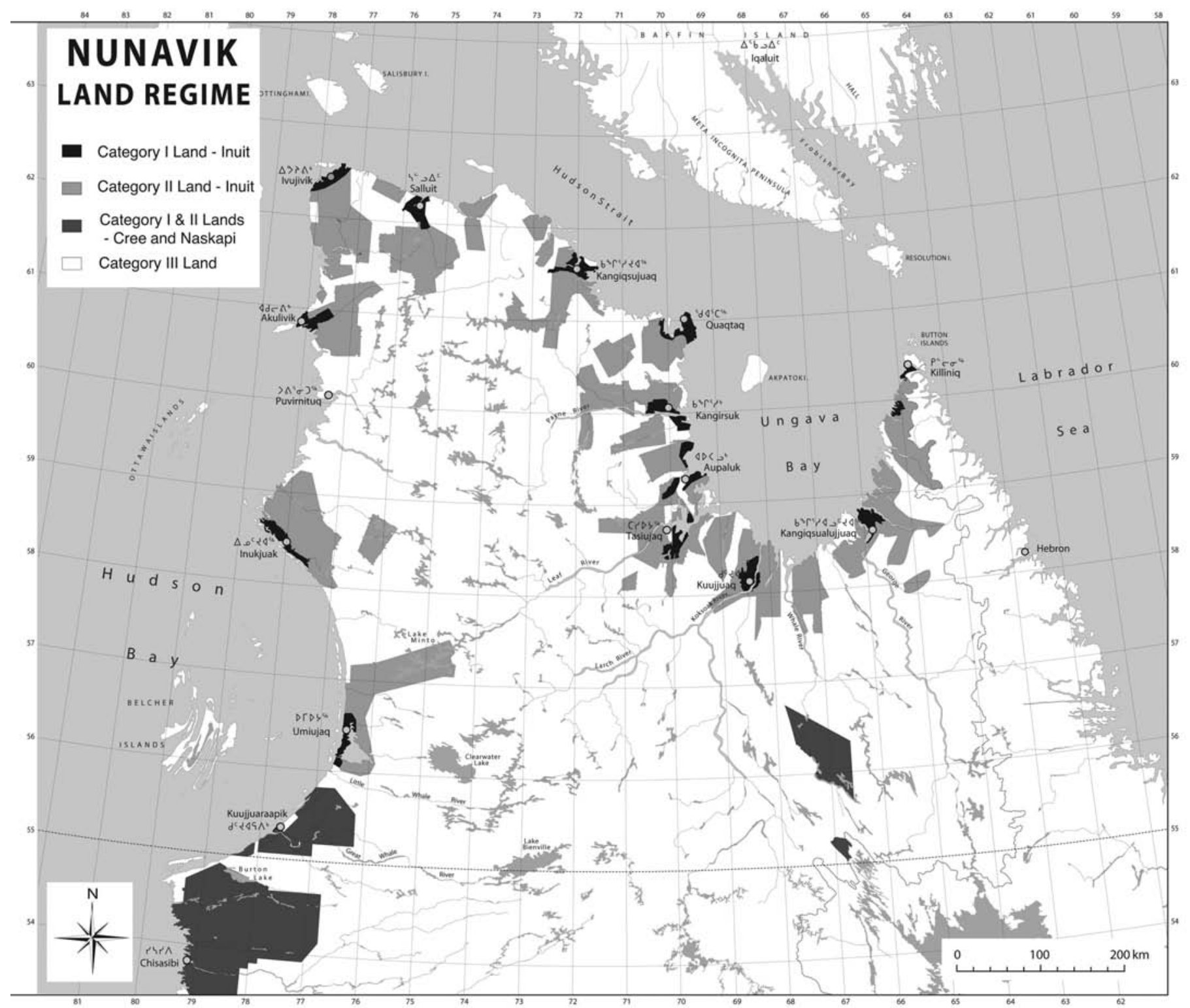

FIG. 1. Nunavik land categories. Map adapted by permission from Cartographic Services, Nunavik Research Centre, Makivik Corporation.

trapping rights thereon. Again, non-beneficiary hunting and fishing may be permitted on these lands by the relevant LHC. Once more, subject to the principle of replacement, the federal and provincial governments may expropriate the lands for development.

Category III designates Crown lands open to access and use by both beneficiaries and non-beneficiaries. Any development of these lands is subject to the co-management regime established under the Agreement (see below). As Brooke (1995) points out, Category I and II lands must absorb the pressures created by policies, programs, and activities on lands designated as Category III. Such pressures are likely to grow as the Plan Nord leads to increased development in Nunavik. Thus, as has happened to Indigenous peoples farther south, the Inuit risk being left without a sustainable land base. Aware of this, in their
Nunavik Inuit Declaration they called for an expanded and adequate land base for wildlife harvesting (Makivik Corporation, 2015).

In its ideal form, then, the JBNQA established legally defined entities, people and property, and the relations between them that distributed access to resources; that is, the basic structure of a wildlife management plan. Under section 24 of the Agreement, unrestricted hunting, fishing, and trapping within Nunavik is legally available only to beneficiaries (subsection 24.3), although this may be subject to limits, including those established by the principle of conservation. Where these are applied in such a way as to affect the Indigenous parties, however, they are ideally meant to be in the form of guidelines or advisory programs. Only if these prove ineffective are more restrictive regulations to be used. Regulations must have a 
minimum impact on beneficiaries, however, and must take into account their food production, sociocultural traditions, access to resources, and economies (Feit, 1979). In contrast, non-beneficiaries' sport hunting and fishing are meant to be more restricted. The practices must respect not only the provincial and federal regulations but also be restricted to Category III lands unless, as previously stated, an LHC permits them on its Category I and II lands. In these cases, non-beneficiaries must also respect the LHC's regulations (see below).

These various elements of the wildlife management regime are woven into a series of formal regulatory structures, some of which are specific to the region, while others apply to supra-regional systems of management. We need, therefore, to understand these administrative structures.

\section{FORMAL CONSTITUENTS OF NUNAVIK'S WILDLIFE MANAGEMENT REGIME}

There is no literature that identifies the various components of existing wildlife management structures in Nunavik. The region has a remarkably fragmented system of governance (Rodon and Grey, 2009; see Wilson, 2017), which is a challenge to anyone seeking to grasp the agencies involved in and regulations applying to wildlife management in Nunavik. Moreover, existing structures may have begun with the signing of the JBNQA in 1975 but have since evolved. For example, prior to the imposition on their territories of settler colonial borders, Inuit harvested lands and waters across what has become Nunavut, Quebec, and Newfoundland and Labrador. To address these areas of overlapping use, the Nunavik Inuit Land Claims Agreement (NILCA) of 2007 was signed by Makivik Corporation and the governments of Canada and Nunavut. The NILCA applies to the offshore region around Quebec, as well as northern Labrador and an offshore area adjacent to Labrador (see Government of Canada, 2008; KRG et al., 2010). It adds another important layer to the regulatory milieu. Yet in addition to the JBNQA and the NILCA, an array of other regulations, laws, agreements, and conventions need to be taken into account to understand the contemporary operation of wildlife management in Nunavik (Table 1). Although these are all in force in theory in Nunavik, in practice, as we shall see, their enforcement has often been challenging.

The official agencies involved in the regulation of wildlife management are many and varied. Some operate within the realm of public government and have responsibility for wildlife in specific environments. These agencies, in turn, are represented in the region by a variety of individual actors, each with specific responsibilities within Nunavik's wildlife management structures (see Table 2). Ideally the agencies and their representatives work together, but appointing the various actors has been a challenge for many public institutions (see below).
In addition to the public agencies, a number of institutions have been mandated to represent exclusively beneficiary or ethnic interests (Table 3 ).

These public and ethnic agencies are meant to work in concert, for example, as members of co-management boards (Table 4). The most influential of these are the Hunting, Fishing, and Trapping Coordinating Committee (HFTCC) and the Nunavik Marine Region Wildlife Board (NMRWB).

According to Feit (1979), the various co-management boards set up under the JBNQA were intended to counterbalance the limited lands on which Indigenous parties to the Agreement have exclusive harvesting rights. They were thus designed to give Indigenous peoples a voice in management decisions made on Category III lands. But researchers have documented limitations on this input caused by underlying power imbalances and a lack of shared cultural understanding with regard to social interactions and wildlife management (see La Rusic et al., 1979; Gagnon, 1982; Brooke, 1995; Peters, 1999, 2003; Nadasdy, 2003; Natcher et al., 2005; Breton-Honeyman et al., 2016). Although these boards were set up to influence decisionmaking within government, they do not in practice challenge government authority to legislate or regulate (La Rusic et al., 1979). Thus, although the NMRWB's authority is greater than that of the HFTCC, government ultimately retains ministerial control over the decisions made by both boards. Hence, for example, in 2016 the governments of Canada and Nunavut changed the South Hudson Bay polar bear quotas set by the NMRWB (Makivik Corporation, 2017).

Clearly the decisions of these co-management boards both affect the activities of, and should rely on input from, Indigenous harvesters. La Rusic et al. (1979) argue that the JBNQA represents one more step in Indigenous peoples' loss of autonomy, decision-making powers, and control over their activities. They contend that the Agreement requires harvesters to become 'managers,' which implies a need for an entity to contain and transmit their management advice. Yet, although paragraph 24.3.24 of the JBNQA made mention of the need for the provincial and federal governments to "take all reasonable measures, within the scope of current programs or those programs which may from time to time be established, including economic measures, to assist the Cree and Inuit parties in establishing trappers' associations" (Gouvernement du Québec, 1998:365), the Agreement did not formally create any agency at the community level to represent Inuit hunters, fishers, and trappers. The associations that have historically existed have therefore had limited and unpredictable funding, generally with operational funds provided by Makivik Corporation and project-related funds from the Kativik Regional Government.

Brooke (1995) suggests that the financial dependence of these local hunting, fishing, and trapping associations (HFTAs) has restricted their freedom to promote their own agendas when these are not shared by their funders. Until recently, Nunavik's HFTAs, whether through their regional 
TABLE 1. Primary wildlife management regulations in effect in Nunavik in 2018.

\begin{tabular}{|c|c|}
\hline Regulatory scale & Wildlife management regulations \\
\hline International & $\begin{array}{l}\text { Convention on Biological Diversity } \\
\text { Convention on International Trade in Endangered Species of Wild Fauna and Flora } \\
\text { International Agreement on Conservation of Polar Bears and their Habitat } \\
\text { International Agreement on Humane Trapping Standards }\end{array}$ \\
\hline National & $\begin{array}{l}\text { Fisheries Act } \\
\text { Marine Mammals Regulations (under the Fisheries Act) } \\
\text { Migratory Birds Convention Act } \\
\text { Navigable Waters Protection Act } \\
\text { Species at Risk Act }\end{array}$ \\
\hline Provincial (Quebec) & $\begin{array}{l}\text { Act Respecting the Conservation and Development of Wildlife } \\
\text { Act Respecting Hunting and Fishing Rights in the James Bay and New Quebec Territories } \\
\text { Regulations for sport hunting and fishing in zone } 23 \text { including permissible locations, appropriate licences, species-specific quotas and } \\
\text { weight restrictions, and species-specific dates for hunting and fishing }\end{array}$ \\
\hline Local & $\begin{array}{l}\text { Regulations defined by each municipality stipulating residency status for non-beneficiaries } \\
\text { Regulations defined by each LHC identifying the hunting and fishing rights of non-beneficiaries on Category I and II lands }\end{array}$ \\
\hline
\end{tabular}

or local associations, have also had no formal status in the various officially established decision-making processes related to its wildlife management (Brooke, 1995; see Suluk and Blakney, 2008 for similar discussion in Nunavut). Only in 2007, as a result of the Nunavik Inuit Land Claim Agreement (subsection 5.7), did the HFTAs (under the titles of LNUKs or Local Nunavimmi Umajulivijiit Katujiqatigininga and the RNUK or Regional Nunavimmi Umajulivijiit Katujiqatigininga) secure both official status in decision-making and limited ongoing funding from the NMRWB. But this authority and funding is restricted to decisions made in the Nunavik Marine Region identified under the NILCA. The lack of funding and official status has hampered the capacities of Inuit hunters, fishers, and trappers at the community level to participate on an ongoing basis in the official administration of wildlife regulations in the region.

According to Feit (1979), the Cree negotiators sought to establish a wildlife management regime that did not hamper the day-to-day activities of harvesters, and so they set up a system that minimized government oversight of their activities (JBNQA paragraph 24.3.30). Perhaps this desire for limited government oversight explains why the HFTAs lacked funding and official status. But this omission might equally reflect the developmental logic of the state that was built into the JBNQA whereby collective rights and cultural practices that fell outside the state's economic objectives were only included in decision-making if it became politically expedient to do so (Tester and Irniq, 2008). Whatever the case, the HFTAs' lack of funding and official status until recently stands in stark contrast to the situation in other Inuit jurisdictions, such as Nunavut, and has limited the capacity of Inuit harvesters to respond to developments affecting their activities. The problem is that it is generally at the local level that the competing and sometimes contradictory dynamics of wildlife management are most acutely experienced, and it is therefore at this level that Inuit harvesters have most needed powerful representation. Moreover, it is at the local level that the various state-sanctioned wildlife management regulations applying to Nunavik have tended to receive minimal oversight, and therefore the enforcement of wildlife regulations has generally been limited.

Due partly to an awareness of this problem, Makivik and a number of individuals involved in the formal representation of the interests of Inuit harvesters have been lobbying the provincial and federal governments to respect the principles of the JBNQA and provide increased funding, training, and presence of enforcement agents in the region. The provincial government has gradually responded, providing increased funding, first, through the Sanarrutik Agreement of 2002 (section 4.5), and later, in 2004, through the Sivunirmut Agreement (section B.4). The question of outcome remains, however. Although the principal laws and regulations identified above have officially been in existence for some time, their actual implementation has been protracted.

\section{ENFORCING WILDLIFE MANAGEMENT REGULATIONS}

Lack of personnel with the power to enforce the wildlife management regulations has been a persistent problem in Nunavik. The enforcement regime of the JBNQA (subsection 24.10) stipulates that the preponderance of those enforcing the wildlife management regulations be Native. In order to achieve this, the governments of Quebec and Canada were required to provide the funding for training of Native conservation officers; modify the criteria required for acceptance to such training; and develop special programs, courses, and training facilities. However, these requirements have only been minimally achieved (see Gagnon, 1982; Brooke, 1995; Coates et al., 2014). According to one informant, for example, in about 1978 a few Inuit were trained and hired seasonally for a couple of years, but the money for the program was not guaranteed and then disappeared. According to Gagnon (1982), the government first attempted to train Native conservation officers in 


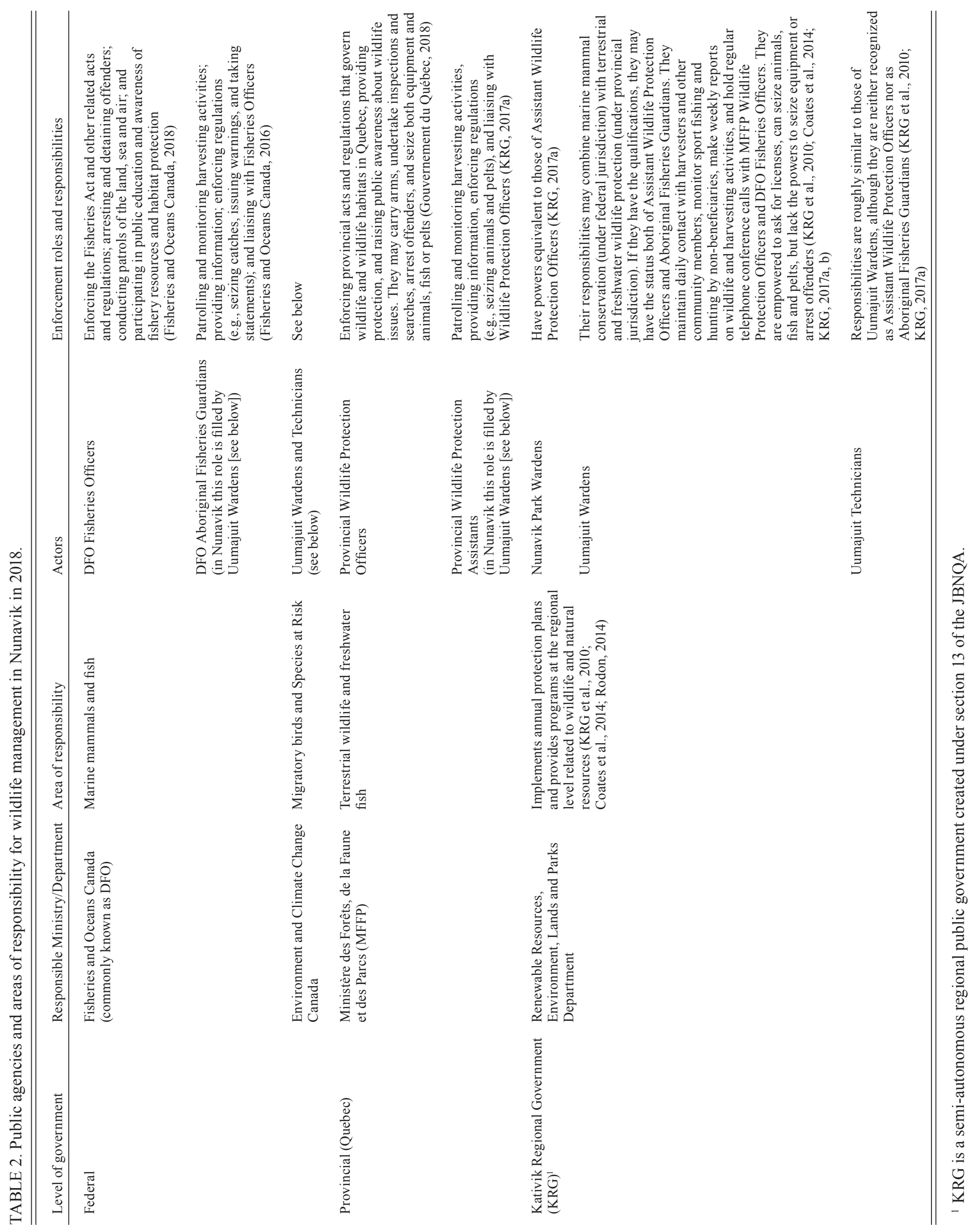


TABLE 3. Ethnic agencies and areas of responsibility for wildlife management in Nunavik in 2018.

\begin{tabular}{ll}
\hline \hline Ethnic agencies & Roles and responsibilities \\
\hline Makivik Corporation, Resource Development Department & $\begin{array}{l}\text { Makivik's general mandate is to protect and represent Inuit rights and interests. } \\
\text { It also manages the financial compensation provided to beneficiaries as a result } \\
\text { of the JBNQA. One Vice-President is responsible for issues related to resource } \\
\text { development, including activities related to wildlife management. It names Inuit } \\
\text { representatives to Nunavik's co-management boards. }\end{array}$ \\
$\begin{array}{ll}\text { Responsible for the administration, promotion and protection of Category I } \\
\text { and II lands, in relation to hunting, fishing and trapping, mining exploration, } \\
\text { environmental protection, and social and economic development. These } \\
\text { corporations exist in the 15 Inuit settlements that signed the JBNQA, and are } \\
\text { collectively represented by the Nunavik Landholding Corporations Association. }\end{array}$ \\
$\begin{array}{ll}\text { Hunting, Fishing and Trapping Association (also known as Anguvigak or, } \\
\text { under the NILCA, as Local Nunavimmi Umajulirijiit Katujjiqatigiinninga for representing the interests of Inuit hunters, fishers, and } \\
\text { [LNUK]) }\end{array}$ & $\begin{array}{l}\text { trappers in Nunavik. The organization, which is made up of locally elected } \\
\text { the NILCA, it informs, gives advice, and makes recommendations to the }\end{array}$ \\
$\begin{array}{l}\text { Nunavik Marine Region Wildlife Management Board concerning the regulation } \\
\text { of Nunavik Inuit harvesting (KRG, 2017a). It exists in all 16 Inuit settlements in } \\
\text { Nunavik. They are collectively represented by a regional HFTA, also known as } \\
\text { the Regional Nunavimmi Umajulirijiit Katujjiqatigiinninga (RNUK). }\end{array}$ \\
\hline \hline
\end{tabular}

TABLE 4. Principal co-management boards related to wildlife management in Nunavik in 2018.

\begin{tabular}{|c|c|c|}
\hline Co-management boards ${ }^{1}$ & Mandate & Membership appointment \\
\hline $\begin{array}{l}\text { Hunting, Fishing, and Trapping } \\
\text { Coordinating Committee (HFTCC) }\end{array}$ & $\begin{array}{l}\text { Established under the JBNQA (subsection 24.4), it is a } \\
\text { consultative body to government that examines and gives } \\
\text { advice about bills, regulations, wildlife management measures, } \\
\text { policies, and decisions that may affect the hunting, fishing, and } \\
\text { trapping regime outlined in the Agreement. All government } \\
\text { authorities must consult and receive recommendations from } \\
\text { the Committee before acting. The responsible Ministers have } \\
\text { discretion as to whether to follow the Committee's advice. } \\
\text { When the responsible Minister modifies or rejects the HFTCC's } \\
\text { recommendations he or she must consult with the Committee. }\end{array}$ & $\begin{array}{l}3 \text { by Makivik, } \\
3 \text { by the Cree Nation Government, } \\
2 \text { by the Naskapi, } \\
4 \text { by the Government of Canada, } \\
4 \text { by the Government of Quebec, and } \\
1 \text { observer by the Société de développement } \\
\text { de la Baie James }\end{array}$ \\
\hline $\begin{array}{l}\text { Nunavik Marine Region Wildlife Board } \\
\text { (NMRWB) }\end{array}$ & $\begin{array}{l}\text { Established under NILCA (subsection 5.2), it is the main } \\
\text { instrument of wildlife management and the main regulator of } \\
\text { access to wildlife in the Nunavik Marine Region (NMR). It } \\
\text { has a research component and stresses the use of both Western } \\
\text { science and Inuit traditional knowledge. It has sole authority } \\
\text { over decisions related to total allowable take and non-quota } \\
\text { limitations of harvesting for all species in the NMR. When the } \\
\text { Minister modifies or rejects a decision by the NMRWB, the } \\
\text { Board may respond with a final decision, which it may also } \\
\text { make public. The Minister must then reconsider and provide } \\
\text { reasons for rejecting or varying the MNRWB's final decision. }\end{array}$ & $\begin{array}{l}3 \text { by Makivik, } \\
2 \text { by the Government of Canada, and } \\
1 \text { by the Government of Nunavut }\end{array}$ \\
\hline
\end{tabular}

\footnotetext{
${ }^{1}$ In addition to the boards listed here, the JBNQA also led to the creation of the Kativik Environmental Advisory Committee, the Kativik Environmental Quality Commission, and the Federal Review Committee North. The NILCA led to the creation of the Nunavik Marine Region Impact Review Board and the Nunavik Marine Region Planning Commission.
}

1980, but struggled as it attempted to impose non-Native educational norms and standards on these individuals. As a result, training was continually delayed. This delay added to the frustrations of the Indigenous parties to the Agreement, who had been lobbying government to respect the commitment. In fact, the lack of both funding and personnel throughout Nunavik has continued to impede the enforcement of existing regulations (KRG et al., 2010). As a provincial bureaucrat acknowledged, it has only really been since the early 2000s that the province has tried to enforce wildlife regulations in Nunavik.
Despite this, in 2006-08 and again in 2018, Inuit who are formally involved in wildlife management in the region continued to voice concerns about the lack of on-theground personnel to enforce regulations. Those with full enforcement capacities (see Table 2) are few and have been based in Kuujjuaq (for terrestrial and freshwater wildlife) or even farther south for marine wildlife. Their capacity to patrol the entirety of Nunavik, let alone charge people with infractions, barely registers against the need. A number of Inuit involved in wildlife management in Nunavik have cited instances where they had been aware of infractions by 
non-beneficiaries - residents of Nunavik and elsewherethat had not resulted in charges laid.

In 2006, Kuujjuaq had two Inuit and one non-Inuit provincial Wildlife Protection Officers fully empowered to enforce and make arrests over infractions of terrestrial and freshwater regulations. By 2018, there were only two nonInuit Wildlife Protection Officers in Kuujjuaq. The result of this change, I was told by Inuit in 2018, was that non-Inuit officers were no longer patrolling with local people and so were less effective because they were unfamiliar with the land, trails, and routes.

In 2007, a government representative told me that as part of the planned expansion of enforcement capacities in Nunavik, the province would set up an office in Inukjuak, with responsibilities for regulating the Hudson Bay coast. However, this has not occurred. I was also informed by various research participants that the federal and provincial governments intended to work with the Kativik Regional Government (KRG) in 2007 to train multidisciplinary, "fully-fledged" officers who would be armed and have all the powers and knowledge necessary to enforce both federal and provincial laws. Such plans had been long in the making. For example, the Sanarrutik Agreement, signed in 2002, provided funding to hire and train six Inuit wildlife protection officers, as well as wildlife protection assistants. This also has not yet been done (see below).

To the extent that Inuit do play a formal role in on-theground enforcement of wildlife management regulations, they generally occupy subordinate administrative positions. The reasons for this reflect the colonial power relations structuring Nunavik's management regime. Inuit, working either as Uumajuit Wardens or Technicians (see Table 2), are based in most of the communities of Nunavik and work with both the federal Department of Fisheries and Oceans (DFO) and the Quebec Ministère des Forêts, de la Faune et des Parcs (Ministry of Forests, Wildlife and Parks [MFFP]). Although it is partially a cost-saving measure, the joint federal and provincial initiative also reflects the struggles, expressed by government representatives, of hiring, training, and retaining Inuit staff. In 2006-08 and again in 2018, federal and regional government administrators said that it was difficult to find Inuit with the requisite education and the willingness, if needed, to charge friends and relatives with legal infractions. I have explored the issue of inducing Inuit to charge their peers with what amount to non-Inuit regulations elsewhere (Gombay, 2019). The question of educational qualifications is an ongoing problem. Despite the stipulation in the JBNQA to modify the training program, the province requires people to take a two-year course to qualify for the position. The course is offered only in French in southern Quebec. As a result, few Inuit occupy these posts, and non-Inuit hold jobs with greater powers of enforcement. Given these limitations, the $\mathrm{KRG}$ is urging the province to respect its commitments and develop alternative approaches to training Inuit.

For the time being, the primary personnel responsible for enforcing regulations across the region are thus the
Uumajuit Wardens and Technicians. Ideally, they should be in each of the 14 settlements of Nunavik; in May 2018, they were in 12 . As one Inuk put it in 2008, they are like "spies" in the settlements providing the eyes and ears and reporting to the government. Another Inuk compared them to the "special constables" used in the past by the Royal Canadian Mounted Police. They were given a certain authority, but denied ultimate control. In this person's estimation it was, "the same old story; we can't have full power." Other beneficiaries spoke of their desire to have co-enforcement powers with the province of Quebec, but doubted it would be granted to them. An Inuk involved in various ethnic organizations repeated this in 2018, saying, "[the Province of] Quebec will never give up wildlife management." These statements echo the observations of Feit (1979) and La Rusic et al. (1979) that, at the time of the JBNQA negotiations, the province was effectively unwilling to loosen its control over wildlife management. The result is that the region has a limited number of people with full enforcement powers. Many Inuit were of the opinion that the province, in not giving up its own power, was also ineffectual by holding on to it.

Although individual Inuit currently have limited powers to enforce wildlife regulations, the JBNQA, through creation of the LHCs, did formally give them a greater role in controlling hunting and fishing by non-Inuit. But again, these powers are restricted by the province. Thus, in addition to being required to follow provincial regulations, non-beneficiaries may also be subject to those imposed by Inuit through their LHCs. To hunt or fish on Category I and II lands, non-beneficiaries must buy permits from appropriate LHCs, with prices varying from settlement to settlement and depending on whether Inuit deem them to be residents. The question of authority to set residency status has caused some confusion. LHCs had understood this to be their prerogative. However, legally these powers lie with the municipal government, a public government agency (paragraphs 24.8.2 and 24.8.4 of the JBNQA). In essence, the province prevents their devolution to ethnically based agencies, retaining the prerogative to determine resource access for itself. To redress this imbalance and ensure greater control over non-beneficiaries' sport hunting and fishing, the Inuit have called for this power to be transferred to the LHCs (Makivik Corporation et al., 2014).

In addition to obliging non-residents to buy permits, the LHCs can also limit the locations where they are allowed to hunt and fish and require them to use outfitters or guides (JBNQA paragraph 24.8.8). In Kuujjuaq, where nonbeneficiaries were known to fish and hunt on Category I and II lands without its permission, the LHC began, in the mid-2000s, to restrict the sites open to non-beneficiaries and to require them to hire a Kuujjuaq beneficiary guide. In 2018 non-Inuit could fish in just two lakes in summer and one in winter. Non-beneficiaries told me it is more difficult to get fish in these locations.

This complex array of actors and regulations has essentially come into being in Nunavik since the 1975 
signing of the JBNQA. Yet the very existence of the regulatory structure begs the question of why it was necessary in the first place.

\section{INUIT PERSPECTIVES ON REGULATION ENFORCEMENT}

According to Feit (1979), at the time of its negotiation, the Indigenous parties to the JBNQA voiced concerns dating back to the 1960s about competing with settlers for wildlife. Indigenous peoples had wanted not only to ensure that the regulations concerning wildlife be applied, but also that they have a voice in their formulation and application. This is one of the objectives that the Agreement was meant to have achieved. During the interviews I conducted between 2006 and 2008, provincial officials generally maintained that a limited number of non-transient, nonbeneficiaries went hunting and fishing without respecting the various regulations in force in Nunavik. In their view, such activities were both limited and diminishing as a result of the increased provincial enforcement of regulations in the early 2000 s. Yet some Inuit felt that not only did they continue to compete with non-Inuit for resources, but also that they needed to have a greater say in wildlife management.

Although some interviewees expressed concern about illegal non-beneficiary hunting and fishing throughout Nunavik, it appeared to be most marked in larger settlements such as Kuujjuaq where the greatest number of non-Inuit are concentrated. In certain instances, nonbeneficiaries were frequenting areas customarily used by beneficiaries (Gombay, 2014). These occurrences seemed particularly problematic in the early 2000 s when large groups of non-beneficiaries went sport fishing or hunting with much expensive equipment and without a beneficiary guide. Their visibility made them the object of resentment amongst Inuit, some of who struggled to afford to go out on the land.

Concern amongst Inuit about poorly regulated sport hunting and fishing by non-beneficiaries has also been voiced elsewhere in the region (KRG et al., 2010). For example, in both 2006-08 and 2018, Inuit expressed disquiet about small aircraft, particularly in the Ungava region, whose passengers fished and hunted without reporting to the authorities or adhering to regulations. Some speculated that the presence of these planes was linked to the greater number of outfitting camps in the region, which allowed transient non-beneficiaries to become more familiar with the region. Pilots seemed to know the limits of the different land categories and would camp just over the border in Category III lands. Inuit also spoke of people who were caught attempting to take Gyrfalcon (Falco rusticolus) eggs (KRG et al., 2010). Partly as a result of these observations, some Inuit had begun to call for better enforcement of the hunting, fishing, and trapping regulations that apply to non-beneficiaries.
Other events however also contributed to the sense that the non-beneficiaries were taking advantage of greater wealth and a regulatory vacuum to gain a form of privileged, illegal access to the region's resources. The sense reflects La Rusic et al.'s (1979) contention that the JBNQA ultimately led to a loss of autonomy over their activities for the Indigenous signatories.

Beneficiaries, in fact, had also been the target of government hunting and fishing regulations. Since the Agreement makes beneficiaries' harvesting subject to principles of conservation, they can also fall foul of state laws. In the mid-2000s, the first case arose concerning beluga hunting, a point of contention long in the making. By the mid-1980s, the DFO had concerns about the status of the beluga population in the waters surrounding Nunavik. In 1996 the agency established the first of a series of beluga management plans designed to control Inuit whale hunting. Although periodically renegotiated, these delimited the numbers harvested, the hunting seasons, and the locations where Inuit could hunt belugas (see Tyrrell, 2008; NMRWB n.d., 2017). As a consequence, in 2005 and 2006 Inuit were charged for hunting beluga in a closed zone and for going over the DFO quotas (George, 2008). The second case involved the provincial government charging a beneficiary for leaving fish in a net for too long. In both cases, although government charges were laid, they were not pursued.

These events caused significant tensions between Inuit and non-Inuit. The second case, where charges were brought for leaving fish in a net, was explained by one Inuk. The fisher had been prevented from checking his nets first by rough weather and then by the death of an elder, which had obliged him to stay in the settlement during a period of mourning. When eventually he did get the fish, following custom, he froze and later fed them to his dogs. The fish were not wasted. Those enforcing the regulations, said the Inuk, did not know Inuit culture; they should not be enforcing regulations in such ignorance. In the case of the beluga, another beneficiary similarly maintained that charging Inuit was inappropriate. The government should have understood that Inuit had, "the yearn[ing] to provide meat for others." This example reflects the long-standing tradition amongst Inuit to share food (see Damas, 1972; Wenzel et al., 2000; Collings, 2011). These events had also resulted in a call by some Inuit for greater enforcement of provincial regulations; if state laws were being applied to them, so should they be applied to non-beneficiaries. Pervading this sentiment was the Inuit view that their perspectives concerning wildlife management were not being given due respect.

If the purpose of wildlife management is to enforce practices deemed to be correct according to a set of beliefs about how to hunt or fish in a manner that conserves the animals, these understandings, and the rules they give rise to, are not held only by the state. Inuit equally have regulations determining correct hunting and fishing procedures (see Fienup-Riordan, 1994, 2007; Hensel, 1996; Oosten et al., 1999). Thus, some beneficiaries spoke about 
the failure of some non-beneficiaries to follow Inuit laws governing hunting and fishing, citing instances where nonInuit took only the hind quarters of caribou rather than the whole animal or used the wrong shot and injured animals without killing them.

If the issue of controlling resource competition is central to any system of resource management, it becomes all the more complex where Indigenous and non-Indigenous peoples, each with their own system of belief and resource management institutions, come into contact with each other. Thus, and not surprisingly, I encountered an array of perspectives in response to the increased enforcement of wildlife management regulations in Nunavik.

\section{PERSPECTIVES ON THE ENFORCEMENT OF REGULATIONS}

The question of the legitimacy of the rules determining access rights to wildlife and the parties to whom these rightfully apply was a recurring theme in my conversations with interviewees. Reasons given for the enforcement of hunting and fishing regulations depended largely on the roles and ethnicities of the individuals concerned (KRG et al., 2010).

As actors of the rational state, non-Inuit provincial and federal agents tasked with the region's resource management held that since the laws existed, they must enforce them (Weber, 1961). Their primary concern was the conservation of resources, which, as a non-Inuit federal employee stated in the case of beluga, meant that,

the government is trying to protect the beluga, because the only people who eat beluga are Inuit. We don't eat them. So [...] we're trying to conserve the species so that the Inuit will be able to enjoy that animal in the future (author's translation from French).

Implicit here is the belief that the state's authority was being appropriately used to ensure the beluga's conservation and that the Inuit ought to recognize this as in their best interests.

Similarly, the logic of conservation governing wildlife regulations seemed fitting and self-evident to many non-beneficiary resource users, who had no concerns about following the rules (Gombay, 2014, 2019). Those interviewed in 2006-08 generally acknowledged that they observed the laws, even though some admitted that the increasingly strict enforcement of regulations that they had experienced since the early 2000 s had been difficult to accept, especially in relation to fishing. In fact, some in Kuujjuaq revealed that they had occasionally hidden their fishing gear as they left the community in the hopes of not being seen. They had been seen, however, as some Inuit to whom I spoke mentioned that they were aware of these occurrences.
Although most non-beneficiaries accepted the state's regulations, some questioned the legitimacy of beneficiary institutions, stressing what they saw as the politics behind the enforcement of these regulations. They felt that the application of Inuit regulations served, not the interests of conservation, but larger reservations on the part of the Inuit about the increasing presence and influence of nonInuit in their territories. Inuit calls for better regulation enforcement, they felt, reflected ethnic tensions. These went both ways, however. One non-Inuit employee of an Inuit organization remarked that since Inuit were systematically breaking hunting regulations, such as the beluga quota, without being charged, some non-beneficiaries felt that they similarly should be allowed to disregard the law. According to this person, non-Inuit questioned why they should have to follow the rules set by Inuit LHCs with respect to their hunting and fishing on Category I and II lands. He went on to say that non-Inuit often failed to understand that the Inuit have legally prioritized harvesting rights under the JBNQA and that LHCs have the right to make decisions about resource use on Category I and II lands.

The tit-for-tat dynamics at play in the region led one nonbeneficiary to state, "[I]f I have to respect the regulations related to hunting and fishing, well then so do they" (author's translation from French). As a consequence, a non-Inuk living in Puvirnituq successfully lobbied the provincial government to permit non-beneficiaries to ice fish in certain locations, despite community opposition. Having opted not to sign the JBNQA, Puvirnituq lacked the land categories and state-sanctioned powers afforded by the Agreement to control non-beneficiary access to resources.

Likewise, it was also noted that, whether as conscious acts of resistance to state laws or as unconscious expressions of respect for their own, Inuit were not necessarily aware of or applying the various state regulations. Inuit are accustomed to hunting and fishing with non-beneficiaries with whom they have social relations, for example. Strengthened regulation enforcement can pose problems for these non-beneficiaries, because no matter what their relations with Inuit, they are required to respect all relevant state laws. Both Inuit and non-Inuit involved in wildlife management thus said that Inuit need to become aware of the application of the JBNQA to non-beneficiaries and stop taking them hunting and fishing.

My interviews made it clear that some Inuit had neither accepted nor internalised government regulations and felt no need to enforce them on non-beneficiaries. Operating on beliefs associated with common property, which contained no place for ownership of land or wildlife, they felt that they had no right to exclude others from hunting or fishing (Gombay, 2014). In addition, the close ties that some had with non-beneficiaries made excluding them on principle from Inuit hunting and fishing trips feel simply wrong.

These feelings and beliefs are coming up against the impacts of an influx of non-beneficiaries to the region, however. A representative of Kuujjuaq's LHC stated in 2007 that the corporation's members had started pressuring 
for enforcement of state-defined regulations. As a result, the LHC had increased the cost of non-beneficiary hunting and fishing permits for its Category I and II lands and waters and, as mentioned, had limited the areas where nonbeneficiary fishing was permitted. As several beneficiaries in both settlements asked, why should non-beneficiaries be allowed to hunt and fish for pleasure when resources are far more valued and significant for Inuit (Rogers, 2016)?

Some non-Inuit bureaucrats responsible for the enforcement of Nunavik's wildlife regulations were aware of many of these tensions and were trying to respond to them. One representative from an Inuit organization commented that he thought the DFO had been trying its best to respond to Inuit complaints and adjust its administration of the beluga quotas. As one provincial regulator commented:

We're the newcomers. We respect their [Inuit] traditions. It's a fact that with the James Bay Agreement we respect their traditions; we respect their ancestral rights. Regulations are enforced [...] in cases of abuse (author's translation from French).

This official went on to say that the province did apply laws selectively. He gave the example of Inuit living in southern Quebec who lose their beneficiary status as a result of having been absent from the territory for more than 10 continuous years (JBNQA paragraph 3.2.7). He had overlooked instances where these Inuit had returned South with country foods after a visit to Nunavik, even though this was against the letter of the law. During the 2006-08 period, non-Inuit bureaucrats from both the provincial and federal governments stressed that they routinely consulted Inuit, periodically visiting each community to ensure that they were responding to people's needs and concerns (KRG et al., 2010). At the same time, some of the government representatives also acknowledged that their community consultations were problematic because Inuit were reticent to share their views about wildlife; they feared that these would be used against them to impose increasingly restrictive quotas in the name of conservation. Moreover, one representative of an Inuit organization involved in wildlife management stated that they had refused to help organize community consultations because doing so might make their organization appear complicit in any future regulations that limited Inuit harvesting. As another Inuk put it in a conversation about government agents, "They try in every way not to do things so others will do it for them."

\section{CHANGES BETWEEN FIRST AND SECOND PHASES OF RESEARCH}

From the research period 2007-08 to that of 2018, some issues had diminished in importance and others had increased. In the earlier period, for example, beluga harvesting was politically charged. By 2018, the Inuit to whom I spoke generally felt that things had settled down. But they warned that tensions could ignite again, particularly with respect to polar bears, whose hunt, Inuit feared, would become increasingly restricted by the government, due to concerns about climate change.

If relations with the DFO over harvesting in marine regions appear to have improved, Inuit were more mixed in their views of the provincial Ministère des Forêts, de la Faune et des Parcs. One representative of an Inuit organization involved in wildlife management said in 2018 that the MFFP continued to have a "colonial attitude and thinking," although he hoped that this would improve as the older generation of bureaucrats retired. In contrast, an Inuk working for another ethnic organization felt that relations with the MFFP had improved over the last decade. A nonInuk involved in wildlife management in the region felt that the MFFP operated on a model that was punitive, like that of the police. He thought that in its work with the Inuit it needed to be more innovative and collaborative, facilitating more Inuit control over the management of wildlife (a view echoed in Parnasimautik). In his opinion the province still operated as it had in the 1980s.

Between 2008 and 2018, falling caribou populations of the George River (George, 2011) and Leaf River (Rogers, 2016) herds were a growing concern. Provincial responses to the issue illustrate some of the difficulties experienced by Inuit in their relations with the province. For instance, Inuit had been demanding the closure of sport hunting of the Leaf River herd for more than three years before the Government of Quebec agreed to do so (Rogers, 2016). Meanwhile, a member of the regional HFTA told me that Inuit had voluntarily restricted their own caribou hunt (UPCART, 2017).

\section{CONCLUSION}

At the outset of this article I posed a number of questions. To what degree have the commitments undertaken by the federal and provincial governments with respect to wildlife management been fulfilled? Given that the Indigenous parties to the JBNQA fought during negotiations to preserve the conditions that would permit them to continue to practice their subsistence activities, what has been the result? Does Brooke's analysis of Nunavik Inuit experiences of wildlife management in 1995 continue to be relevant?

As we have seen, the difficulties that Brooke identified in 1995 persist. Poor communication, lack of a common system of belief, the undermining of Inuit systems of management, insufficient funding, and so on, are all ongoing. Of particular importance are ongoing problems associated with the existence of complex administrative structures and insufficient power-sharing.

The various agencies, actors, laws, and regulations outlined in this article have all come into being in the region since 1975. Prior to that Inuit essentially regulated their own hunting, fishing, and trapping with minimal government interference. Forty years after the Agreement was signed, 
the wildlife management regime in Nunavik has evolved. The NMRWB expanded the powers and areas covered by the region's co-management boards. Inuit, through the Uumajuit Wardens program, are more involved in the enforcement of rules, albeit with lesser powers than were stipulated in the JBNQA. Inuit have become increasingly adept at recognising and manoeuvring their way through the structures and processes that define the region's contemporary wildlife management system. The system itself, however, continues to develop and be administered through a complex network of bureaucratic structures. A remarkable number of agencies and boards are involved in the region's wildlife management. Taking only the case of the co-management boards, there are seven in total. It would be interesting to compare the ways in which other jurisdictions manage (to avoid) similarly complex structures. The Inuvialuit Settlement Region, for example, has a Joint Secretariat that coordinates its co-management boards.

Power sharing between Inuit and non-Inuit government agencies continues to be problematic. As Brooke (1995) points out, the limited authority the Agreement gave Inuit over their lands and resources ensured that it could not be easily used to promote power sharing. Genuine power sharing, she argues, would require self-government, which is not in effect in Nunavik. Involvement of Inuit in decisionmaking has been strengthened (e.g., through the NILCA) but their role needs to be further strengthened. Despite the fact that the enforcement of regulations continues to be hampered by limited personnel with full powers, and despite the JBNQA's commitment that these roles would be primarily occupied by Inidigenous peoples, the training and hiring of fully empowered Inuit game wardens appears to have stalled. The provincial and federal governments must respect their JBNQA commitment to find appropriate mechanisms for training and hiring that are adapted to local needs and realities. The Kativik Regional Government has been pushing for a revamping of the training of Inuit Conservation Officers and Fisheries Officers, so that the process of devolution may continue.

The devolution of powers is clearly an ongoing issue. For many Inuit in Nunavik the status quo will not do; they want self-government. In fact, having completed negotiations to that end, in a popular referendum in 2011, they rejected a proposed agreement to create a Nunavik Regional Government. This rejection was, in part, because the province insisted it be a public, rather than an ethnic government (Rodon and Grey, 2009); Inuit felt that a public government would not sufficiently reflect or promote their values and desire for self-government (Papillon, 2011; Hervé, 2017a, b). In the realm of wildlife management, such devolution of power requires both the regional and local HFTAs be given a strong, effective, and independent voice to represent local harvesters. The Inuvialuit Final Agreement and the Nunavut Agreement both gave funding and an official role to similar organizations. The same should be done in Nunavik so that the regional and local HFTAs can participate in all decisions, not only those covered by the NILCA. Fully funded and officially sanctioned participation by the HFTA in all realms of decision-making related to wildlife management has the potential to ensure that management systems will be guided by Inuit values and concepts central to their subsistence practices. In the long term, the success of the JBNQA and its partner agreement, the NILCA, must be judged on the issue of whether they have indeed fulfilled their commitments and enabled the Indigenous signatories to continue their subsistence practices. The ongoing impacts of climate change, coupled with Quebec's Plan Nord, make the development of effective co-management in the region all the more necessary.

\section{ACKNOWLEDGEMENTS}

My thanks to all who contributed to this research. Thanks, too, to Kaitlin Breton-Honeyman and three anonymous reviewers for their comments.

\section{REFERENCES}

Alfred, T.R. 2005. Wasáse: Indigenous pathways of action and freedom. Peterborough, Ontario; Orchard Park, New York: Broadview Press.

Banner, S. 1999. Two properties, one land: Law and space in nineteenth-century New Zealand. Law \& Social Inquiry 24(4):807-852.

https://doi.org/10.1111/j.1747-4469.1999.tb00406.x

Breton-Honeyman, K., Furgal, C.M., and Hammill, M.O. 2016. Systematic review and critique of the contributions of traditional ecological knowledge of beluga whales in the marine mammal literature. Arctic 69(1):37-46.

https://doi.org/10.14430/arctic4543

Brooke, L.F. 1995. Experiences of the Nunavik Inuit with wildlife management and the James Bay and Northern Quebec Agreement (1975-1995). Research Report. Ottawa: Royal Commission on Aboriginal Peoples.

http://data2.archives.ca/rcap/pdf/rcap-21.pdf

Canadian Polar Commission. 2014. State of northern knowledge in Canada.

http://www.polarcom.gc.ca/sites/default/files/snk_report english.pdf

Canobbio, E., 2009. Géopolitique d'une ambition inuite: Le Québec face à son destin nordique. Québec: Les éditions du Septentrion.

Coates, K., Holroyd, C., and Leader, J. 2014. Managing the forgotten North: Governance structures and administrative operations of Canada's provincial Norths. The Northern Review 38:6-54.

Collings, P. 2011. Economic strategies, community, and food networks in Ulukhaktok, Northwest Territories, Canada. Arctic 64(2):207-219.

https://doi.org/10.14430/arctic4100 
Coulthard, G.S. 2014. Red skin, white masks: Rejecting the colonial politics of recognition. Minneapolis: University of Minnesota Press. https://doi.org/10.5749/minnesota/9780816679645.001.0001

Damas, D. 1972. Central Eskimo systems of food sharing. Ethnology 11(3):220-240. https://doi.org/10.2307/3773217

Fabbi, N.C., Rodon, T., and Finke, E.W. 2017. Makippugut (we are standing up): Public policy and self-determination in Nunavik. American Review of Canadian Studies 47(2):117-126. https://doi.org/10.1080/02722011.2017.1323824

Feit, H.A. 1979. Political articulations of hunters to the state: Means of resisting threats to subsistence production in the James Bay and Northern Quebec Agreement. Études/Inuit/ Studies 3(2):37-52.

Fenge, T. 2008. Implementing comprehensive land claims agreements. Policy Options Politiques.

http://policyoptions.irpp.org/magazines/quebec-1608-2008/ implementing-comprehensive-land-claims-agreements/

—. 2013. Modern treaties: Implementing the Nunavut agreement and other modern treaties: Does the government of Canada "get it"? Northern Public Affairs 1(3):36-38.

Fienup-Riordan, A. 1994. Boundaries and passages: Rule and ritual in Yup'ik Eskimo oral tradition. Norman: University of Oklahoma Press.

2007. Compassion and restraint: The moral foundations of Yup'ik Eskimo hunting tradition. In: Laugrand, F.B., and Oosten, J.G., eds. La nature des esprits dans les cosmologies autochtones/Nature of spirits in Aboriginal cosmologies. Québec: Les presses de l'Université Laval. 241-253.

Fisheries and Oceans Canada. 2016. First cohort of Aboriginal fishery guardians trained in Québec. Infoceans Quebec Bulletin 19(4).

http://www.qc.dfo-mpo.gc.ca/infoceans/201608/article3-eng. html

- 2018. Lifestyle of a fishery officer: Work description. http://www.dfo-mpo.gc.ca/career-carriere/enf-loi/descriptioneng.htm\#a3

Gagnon, J.A. 1982. Le régime de chasse, de pêche et de trappage et le conventions du Québec nordique. Québec: Centre d'études nordiques, Université Laval.

George, J. 2008. Makivik urges compliance, other groups oppose DFO. Nunatsiaq News, April 17.

http://old.nunatsiaq.com/stories/article/Makvik_urges compliance_other_groups_oppose_DFO/

- 2011 Nunavik caribou numbers in rapid free-fall: George River herd drops by 80 per cent. Nunatsiaq News, May 25.

https://nunatsiaq.com/stories/article/25667_nunavik_caribou_ numbers_in_rapid_free-fall/

Gombay, N. 2014. 'Poaching' - what's in a name? Debates about law, property, and protection in the context of settler colonialism. Geoforum 55:1-12.

https://doi.org/10.1016/j.geoforum.2014.04.010

. 2019. "There's no one way of doing things": Wildlife management and environmentality in Nunavik. Hunter and Gatherer Research 3(4):651-675.

https://doi.org/10.3828/hgr.2017.33
Gouvernement du Québec. 1998. James Bay and Northern Québec Agreement and Complementary Agreements. Les Publications du Québec: Sainte-Foy, Québec.

. 2015. The Plan Nord 2015 - 2020 action plan: Toward 2035. https://plannord.gouv.qc.ca/wp-content/uploads/2015/04/ Synthese_PN_EN_IMP.pdf

- 2018. L'équipe au travail.

http://mffp.gouv.qc.ca/la-faune/protection-de-faune/equipeau-travail/

Government of Canada. 2008. Nunavik Inuit land claims agreement.

https://laws-lois.justice.gc.ca/eng/acts/N-28.5/index.html

Grammond, S. 2008. L'appartenance aux communautés inuit du Nunavik: Un cas de réception de l'ordre juridique inuit? Canadian Journal of Law and Society 23(1-2):93 - 119.

https://doi.org/10.1017/S0829320100009595

Hensel, C. 1996. Telling our selves: Ethnicity and discourse in southwestern Alaska. Oxford: Oxford University Press.

Hervé, C. 2017a. The social life of political institutions among the Nunavik Inuit (Arctic Québec, Canada). In: Fondahl, G., and Wilson, G.N., eds. Northern sustainabilities: Understanding and addressing change in the circumpolar world. Cham, Switzerland: Springer International Publishing. 95-105. https://doi.org/10.1007/978-3-319-46150-2_8

. 2017b. Wrapped in two flags: The complex political history of Nunavik. American Review of Canadian Studies 47(2):127- 147. https://doi.org/10.1080/02722011.2017.1323912

ITN (Inuit Tungavingat Nunamini). 1977. Les Inuit dissident à l'entente de la Baie James. Montréal: Les Publications la maîtresse d'école.

KRG (Kativik Regional Government). 2017a. Uumajuit warden program. Presentation to Kativik Regional Government Council meeting February 2017. The Renewable Resources, Environment, Lands and Parks Dept. PO Box 9, Kuujjuaq, Quebec J0M 1C0, Canada.

. 2017b. Uumajuit program.

http://www.krg.ca/krg-departments/renewable-resources/ wildlife-conservation

KRG (Kativik Regional Government) and Makivik Corporation. 2010. Plan Nunavik. Westmount, Québec: Avataq Cultural Institute.

KRG (Kativik Regional Government), Environment Canada, Fisheries and Oceans Canada, and Ministère des Ressources naturelles et de la Faune, Québec. 2010. Working together to protect wildlife and wildlife habitat, and to promote the sustainable use of wildlife resources in Nunavik. Five Year Protection Plan 2010-2015.

http://www.krg.ca/images/stories/docs/Wildlife Conservation/Nunavik\%20Wildlife $\% 20$ Protection $\% 2 \overline{0}$ Plan\%202010-2015\%20eng_2.pdf

Kulchyski, P. 2015. Trail to tears: Concerning modern treaties in northern Canada. The Canadian Journal of Native Studies 35(1):69-81.

La Rusic, I.E., Bouchard, S., Penn, A., Brelsford, T., Deschênes, J.-G., and Salisbury, R.F. 1979. Negotiating a way of life. Ottawa: Department of Indian and Northern Affairs. 
Makivik Corporation. 2015. 2015 Nunavik Inuit Declaration: Proud, united and determined. http://parnasimautik.com/2015-nunavik-inuit-declaration/

—. 2017. Annual Report 2016-2017.

Makivik Corporation, Kativik Regional Government, Kativik School Board, Nunavik Landholding Corporations Association, Saputiit Youth Association of Nunavik, Nunavik Regional Board of Health and Social Services, and Avataq Cultural Institute. 2014. Parnasimautik consultation report: On the consultations carried out with Nunavik Inuit in 2013. http://www.parnasimautik.com/wp-content/uploads/2014/12/ Parnasimautik-consultation-report-v2014_12_15-eng_vf.pdf

McCarthy, T. 2013. Modern treaties: Sources of funds, sources of frustrations. Northern Public Affairs 1(3):26-33.

Nadasdy, P. 2003. Hunters and bureaucrats: Power, knowledge, and Aboriginal-state relations in the southwest Yukon. Vancouver: University of British Columbia Press.

Natcher, D.C., Davis, S., and Hickey, C.G. 2005. Co-management: Managing relationships, not resources. Human Organization 64(3):240-250.

https://doi.org/10.17730/humo.64.3.23yfnkrl2ylapjxw

NMRWB (Nunavik Marine Region Wildlife Board). n.d. Summary of the 2014-2017 beluga management system. PO Box 433, Inukjuaq, Quebec J0M 1M0.

2017. Resolution \# 2017-03-05: A resolution to establish the total allowable take and non-quota limitations for eastern Hudson Bay beluga in the Nunavik Marine Region, excluding the Cree/Inuit overlap area. Inukjuak, Québec: NMRWB.

https://nmrwb.ca/public-information/\#75-wpfd-2017resolutions

Nungak, Z. 2017. Wrestling with colonialism on steroids: Quebec Inuit fight for their homeland. Montreal: Véhicule Press.

Oosten, J., Laugrand, F., and Rasing, W. 1999. Perspectives on traditional law. Iqaluit: Language and Culture Program, Nunavut Arctic College.

Orkin, J. 2013. Modern treaties: Keeping the promise: the implementation of modern treaties in Canada. Northern Public Affairs 1(3):23-25.

Otis, G. 2002. Inuit subsistence rights under the James Bay and Northern Quebec Agreement: A legal perspective on food security in Nunavik. In: Duhaime, G., ed. Sustainable food security in the Arctic: State of knowledge. Occasional Publications Series No. 52. Edmonton: University of Alberta, CCI Press; Université Laval, GÉTIC. 189-195.

https://www.uap.ualberta.ca/book-images/Open $\% 20$ Access/9781772122435_WEB.pdf

Papillon, M. 2011. Le référendum au Nunavik: Un pas en arrière pour mieux avancer? Option Politiques/Policy Options August 2011:10-14.

Peters, E.J. 1999. Native people and the environmental regime in the James Bay and Northern Québec Agreement. Arctic 52(4):395-410. https://doi.org/10.14430/arctic944

- 2003. Views of traditional ecological knowledge in co-management bodies in Nunavik, Quebec. Polar Record 39(1):49-60.

https://doi.org/10.1017/S0032247402002759
Qumaq, T. 2010. Je veux que les Inuit soient libres de nouveau: Autobiographie (1914-1993). Québec: Presses de l'Université du Québec.

Rodon, T. 2014. Le Nunavut: Une composition inachevée? Études/ Inuit/Studies 38(1-2):95-114. https://doi.org/10.7202/1028855ar

Rodon, T., and Grey, M. 2009. The long and winding road to selfgovernment: The Nunavik and Nunatsiavut experiences. In: Abele, F., Courchene, T.J., Siedle, F.L., and St-Hilaire, F., eds. Northern exposure: Peoples, powers and prospects in Canada's North. Montreal: Institute for Research on Public Policy. 317-344.

Rodon, T., and Schott, S. 2014. Towards a sustainable future for Nunavik. Polar Record 50(3):260-276. https://doi.org/10.1017/S0032247413000132

Rogers, S. 2016. Nunavik Inuit demand closure of Leaf River Caribou sports hunt. Nunatsiaq News, December 20.

http://www.nunatsiaqonline.ca/stories/article/65674nunavik_ inuit_demand_Quebec_close_leaf_river_caribou_sports_ hunt/

Rouland, N. 1978. Les Inuit du Nouveau Québec et la convention de la Bai James. Québec: Association Inuksiutiit Kataimajiit.

Schlager, E., and Ostrom, E. 1992. Property-rights regimes and natural resources: A conceptual analysis. Land Economics 68(3):249-262. https://doi.org/10.2307/3146375

Singer, J.W. 2000. Entitlement: The paradoxes of property. New Haven, Connecticut: Yale University Press.

Suluk, T.K., and Blakney, S.L. 2008. Land claims and resistance to the management of harvester activities in Nunavut. Arctic 61(Suppl. 1):62-70.

https://oi.org/10.14430/arctic102

Tester, F.J., and Irniq, P. 2008. Inuit Qaujimajatuqangit: Social history, politics and the practice of resistance. Arctic 61(Suppl. 1):48-61.

https://doi.org/10.14430/arctic101

Tyrrell, M. 2008. Nunavik Inuit perspectives on beluga whale management in the Canadian Arctic. Human Organization 67(3):322-334.

https://doi.org/10.17730/humo.67.3.47826252k0623352

UPCART (Ungava Peninsula Caribou Aboriginal Round Table). 2017. A long time ago in the future: Caribou and the people of Ungava. UPCART 2017-2117. $\mathrm{x}+47 \mathrm{p}$.

Weber, M. 1961. General economic history. New York: Collier Books.

Wenzel, G.W., Hovelsrud-Broda, G., and Kishigami, N., eds. 2000. The social economy of sharing: Resource allocation and modern hunter-gatherers. Senri Ethnological Studies No. 53. Osaka: National Museum of Ethnology.

Wilson, G.N. 2017. Nunavik and the multiple dimensions of Inuit governance. American Review of Canadian Studies. 47(2):148-161.

https://doi.org/10.1080/02722011.2017.1323995 